\title{
DeVElopMent OF SHOPPING CENTERS IN CENTRAL AND SOUTHEASTERn EUROPE
}

\author{
DELIC, M. \& KNEZEVIC, B.
}

Abstract: Shopping centers play an important role in improving the quality of life in town and city centers around the world. Often seen as drivers of local economies, shopping centers are necessary to maintain economic growth and a sense of community, offering employment, and providing a better quality of life. In last decades in all capital cities and large cities in Central and Southeastern Europe numerous shopping centers were open and therefore the situation at retail market and traditional supply chains changed rapidly. The aim of this paper is to provide key data related to shopping center industry in Central and Southeastern European countries and to analyze the structure of retail offers, opportunities for investors, retailers and consumers at given markets. Comparative analysis of secondary data will give an insight into the current state of shopping center development and discuss the problems related to future retail development in Southeastern Europe.

Key words: shopping centers, retail industry, Central Europe, Southeastern Europe, retail development.
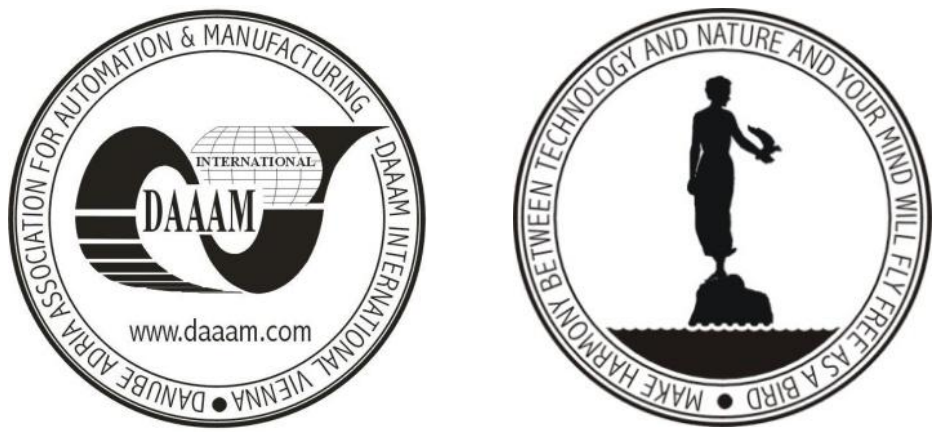

Authors' data: Delic, M[ia]; Univ.Prof. Dr. Sc. Knezevic, B[lazenka], Faculty of Economics and Business, J. F. Kennedy 6, 10000, Zagreb, Croatia, mdelic@efzg.hr, bknezevic@efzg.hr

This Publication has to be referred as: Delic, M[ia] \& Knezevic, B[lazenka] (2014). Development of Shopping Centers in Central and Southeastern Europe, Chapter 38 in DAAAM International Scientific Book 2014, pp.471-484, B. Katalinic (Ed.), Published by DAAAM International, ISBN 978-3-901509-98-8, ISSN 17269687, Vienna, Austria

DOI:10.2507/daaam.scibook.2014.38 
Delic, M. \& Knezevic, B.: Development of Shopping Centers in Central and Southea...

\section{Introduction}

Shopping center can be described as a group of retail and other commercial establishments planned and developed as a single entity with a single administration. Basic functions of shopping centers are commercial and social functions.

Shopping centers have a hundred year old tradition. While there were a few forerunners, the shopping center really became a firmly established part of the American scene in the late 1950s and 1960s (White \& Gray, 1996). The first contemporary shopping centers in Europe appeared in Nordic countries in late 1960s (Segetlija, 2006). The dynamics of the construction of new shopping centers in Europe was particularly pronounced during the period from 2005 to 2008. The crisis and recession in 2009 slowed down the construction of new shopping centers, where construction is not stopped, but only postponed until further notice.

Since 1950, the percent of retail sales occurring in shopping centers has grown rapidly. By 1974, it was estimated that more than 25 percent of all nonautomotive retail sales were made in shopping centers. By 1982, the percentage had risen to almost 42 percent, and, by 1996, it was an estimated 52 percent (Beyard \& O'Mara, 2006).

Shopping centers provide the 'delivery infrastructure' for the efficient connection of consumers with goods and services and can act as a multiplier of retail sales volume by way of a targeted, planned tenant mix with complementary occupiers in close proximity to one another in order to maximize footfall and cross-shopping. Through this infrastructure, shopping-center industry sales provide a window on the consumers' and economy's health, a vehicle to collect sales taxes for governments and a place for jobs in the community (ICSC EUROPE, 2012).

The modern European shopping center came into existence in Sweden in the mid1950s. Shopping in Lulel was opened in 1955 and was the first purposely built indoor shopping center in Europe. During the 60s and 70s shopping centers spread across Europe, first in Great Britain and France and then in other west European countries like Spain and West Germany. The development of the shopping center followed the development of higher incomes and greater mobility of consumers as well as the growth of more and larger chain stores (NCSC, 2009).

In global markets, shopping centers are becoming important agents, defining the kind and quality of intangible features of supplies, not only establishing the assortments, but also affecting the consumption behavior atmosphere that they determine in all its aspects.

The following elements characterize the well-planned shopping center and set it apart from other commercial land uses (Beyard \& O’Mara, 2006):

- A unified architectural treatment, concept, or theme for the building, providing space for tenants that are selected and managed as a unit for the benefit of all tenants.

- Unified site, suited to the type of center called for by the market, and easily accessible location within the trade area with adequate entrances and exits.

- Sufficient on-site parking to meet demand generated by the retail uses.

- Service facilities for the delivery of merchandise. 
- Site improvements, such as landscaping, lighting, and signage, that creates a desirable, attractive and safe shopping environment.

- Comfortable surroundings for shopping and related activities that create a strong sense of identity and place.

Shopping centers are often created around an anchor store that represents the main attraction for the clientele. Shopping centers often have a supermarket as their anchor, but a growing number of themed centers are developing, addressing specific market targets, where the anchor may be a multiplex cinema, entertainment or fitness facilities, plus, obviously, a significant number of catering establishments, for example: Disneyland, Gardaland, Amsterdam Arena (Markerink \& Santini, 2004).

Shopping centers share the goal of attracting clients in order to generate selling conditions for the stores in the center. The traditional social meeting places that caused cities to grow (in terms of covered area, population and wealth produced and consumed) and typically originated from a mixture of economic and religious activities (the main square, commercial and religious life, and the high street), are now tending to be replaced to a large extent by shopping centers. Consumption and the purchasing activity that precedes it, tends to become crucial in global markets, while purchasing and consumption centers, like shopping centers, become the economic and social meeting places (Corniani, 2011).

The shopping center industry is worthy of study for many reasons. While the shopping center may be most often thought of as a form of real estate, it is also the most powerful distribution system for retail goods.

Based on the critical literature review, this paper will explain characteristics and importance of the market of shopping centers. Then, on the basis of previously conducted research studies, paper will highlight the current state of the market of shopping centers and possible future development trends in selected countries of Central and Southeastern Europe.

\section{The European market of shopping centers}

According to Jean-Louis Solal, market pioneer of modern shopping centers, the first modern shopping center in Europe appeared in the Nordic countries; it was "Vällingby Centrum" in Sweden built in 1950. But the first real regional centers were Parly 2 (Paris) and Cap (Nice) built in the late 1960s, modeled on the American shopping mall (Šulmajster Šodić, 2008).

The first shopping center with hypermarket in Europe emerged in 1974 (Šulmajster Šodić, 2008) and became the model for most southern European shopping centers, particularly in Spain, Portugal and Italy, and this concept is still popular in Eastern European countries. Across Europe become widespread and "commercial parks" that expand the concept of traditional shopping centers and include theaters, bowling alleys, fitness centers, hotels, restaurants and other facilities for rest and recreation.

Shopping centers have been expansively developed in the economic booming period before September 2008. Due to the financial and economic crisis the real estate industry has been gravely affected. The shopping center industry is also not an exemption from this, especially not in emerging markets (Reikli, 2013). 
The importance of shopping center sales to the European economy is proportional to its contribution to retail sales. Shopping center penetration of retail sales is high in mature markets and is rising rapidly in other European countries, particularly in Central and Eastern Europe where there has been rapid expansion of the shopping center market in recent years. Retail sales (except of motor vehicles and motorcycles) in the EU-27 totaled $€ 2,687$ billion in 2012 . The International Council of Shopping Centers estimates that shopping center sales in the EU-27 accounted for 19\% of total retail sales and reached $€ 511.9$ billion in 2012 . There was a pronounced gap between the prospering and struggling nations where positive sales growth in Central Europe was offset by negative growth in many southern European countries, such as Greece, Cyprus, Spain and Portugal, as consumption continues to be affected by high unemployment, stringent Government budgeting measures and low expectations for economic development (ICSC EUROPE, 2012).

\subsection{The impact of the global financial crisis on shopping center market in Europe}

Majority of shopping center investment was made just before the crisis, when prices were on its peak, so this will prolong the payback period for the investors. The global economic crisis has led to major consequences and completely turned the manner and speed of entry into large investment projects and caused a strategic change in business operations and decision-making in international business. Socio-cultural changes make global changes in lifestyle and behavior towards consumption in the retail market.

The recession that hit Europe following the sovereign debt crisis ended in 2013 as the Eurozone shifted from contraction to modest growth. Real GDP for Europe as a whole increased $0.5 \%$ in 2013 after contracting $-0.1 \%$ in 2012. Stronger growth is projected for 2014 and 2015 as the economic strains in the peripheral nations diminish while the core countries accelerate steadily. In the Eurozone consumer spending is expected to grow 1.0\% in 2014 after contracting in 2013, helping to boost outlays for Europe as a whole by approximately $1.3 \%$ (Global Shopping Center Development Report: Americas, Europe, Asia, 2014).

Development activity across Europe picked up considerably in the second half of 2013 as approximately 3.6 million sq. m of new shopping center GLA was delivered to the market. Total shopping center floor-space now stands at approximately 154 million sq. m of GLA (Global Shopping Center Development Report: Americas, Europe, Asia, 2014).

Central and Eastern Europe accounted for almost $65 \%$ of all new shopping center space added in 2012. This is largely the result of several markets experiencing delays with developments, which consequently pushed them into the pipeline for 2013 . The projected total for 2013 is $7 \mathrm{mn}$ sq. m, with $70 \%$ estimated to be delivered in Central and Eastern European markets (Marketbeat Shopping Center Development Report Europe, 2013).

Worldwide investments in commercial real estate rose considerably throughout the last year - a sum of EUR 165.6 billion was invested in commercial real estate in Europe last year, i.e. a rise of around 30\% compared with 2012 (Fig. 1). 


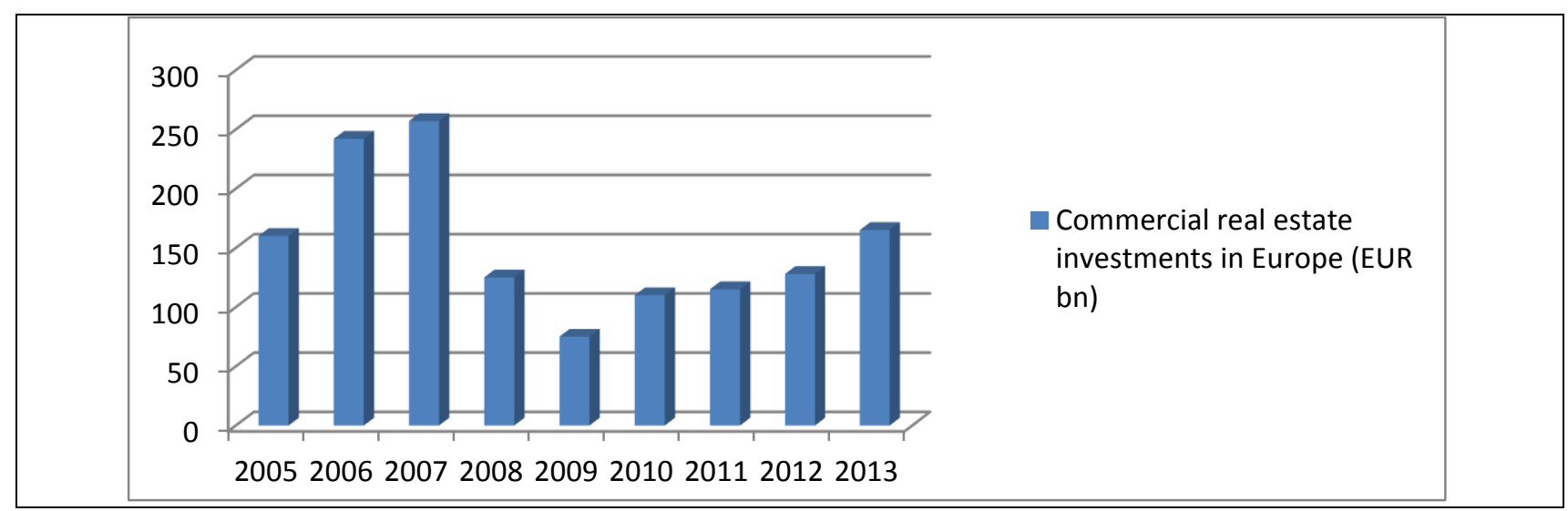

Fig. 1. Commercial real estate investments Europe Source: Real Estate Country Facts, 2014

There was still great demand for real estate in Central and Eastern Europe. Poland, the largest market in the region, profited most from strong demand. However, there are now some indications that smaller real estate markets are no longer being neglected. Czech Republic investment volume increased to more than EUR 1 bn in 2013 and at least individual transactions were also concluded in other smaller CEE markets (Tab. 1).

\begin{tabular}{|l|l|l|}
\hline Country & 2012 & 2013 \\
\hline Bulgaria & 9 & 23 \\
\hline Croatia & 43 & 67 \\
\hline Czech Republic & 605 & 1015 \\
\hline Hungary & 121 & 225 \\
\hline Poland & 2720 & 2970 \\
\hline Romania & 185 & 229 \\
\hline Slovakia & 16 & 250 \\
\hline Ukraine & 249 & 41 \\
\hline
\end{tabular}

Tab. 1. Commercial real estate investments in selected Central and Southeastern countries in 2012 and 2013

Overall, the region saw real signs of economic improvement, better finance availability, stronger occupier markets and a repositioning along the risk curve by investors, all factors which spurred a rise in investment activity. However, with a shortage of good quality assets and constrained development activity limiting the number of opportunities in some core markets, investors will again be looking further afield in other previously overlooked countries (Global Shopping Center Development Report: Americas, Europe, Asia, 2014).

How fast will investors move towards riskier countries of Central and Eastern Europe in search for good opportunities depends on future economic stability and the willingness of banks to finance projects.

\section{Development trends of shopping centers in Central and Southeastern Europe}

Before embarking on the development of a new shopping center or the repositioning of an existing center, a developer must identify and evaluate the retail 
market - the supply and demand of retail offerings - and calculate the potential patronage for various categories of goods and services (Beyard \& O'Mara, 2006).

The first component of market demand analysis is, in many ways, the most important. Defining the trade area in which a store or center will compete draws on the analysis of area demand, local consumer preferences, and the existing and planned competition. For the developer of a retail facility or a retailer entering or expanding in a market, trade area analysis includes quantifying and qualifying achievable sales volumes, but also selecting the locations within the area that optimize market share and profitability. It remains for the investor to appraise the long-term viability of the trade area and the role of the property within it.

Central and Eastern Europe continued to drive activity, accounting for $69 \%$ of all shopping center space added to the market ( 2.4 million sq. m). Additionally, the region is expected to remain a development hotspot, with $66 \%$ of all projected space to be completed in 2014 and 2015 across Europe (6.8 million sq. m) and 4.2 million sq. $\mathrm{m}$ respectively is set to be delivered in Central and Eastern Europe. While the pipeline for 2015 is expected to slow, geopolitical concerns in Eastern Europe may lead to the postponements of some projects into next year (Global Shopping Center Development Report: Americas, Europe, Asia, 2014).

\begin{tabular}{|l|c|c|}
\hline \multicolumn{1}{|c|}{ Country } & $\begin{array}{c}\text { Number of shopping } \\
\text { centers in operation }\end{array}$ & $\begin{array}{c}\text { Number of shopping } \\
\text { centers in the pipeline }\end{array}$ \\
\hline Albania & 17 & 2 \\
\hline Austria & 148 & 43 \\
\hline $\begin{array}{l}\text { Bosnia \& } \\
\text { Herzegovina }\end{array}$ & 38 & 5 \\
\hline Bulgaria & 44 & 43 \\
\hline Croatia & 59 & 22 \\
\hline Czech Republic & 115 & 41 \\
\hline Germany & 593 & 142 \\
\hline Greece & 26 & 2 \\
\hline Hungary & 95 & 17 \\
\hline Italy & 607 & 35 \\
\hline Kosovo & 4 & 3 \\
\hline Macedonia & 16 & 5 \\
\hline Moldova & 10 & 0 \\
\hline Montenegro & 4 & 2 \\
\hline Poland & 324 & 174 \\
\hline Romania & 115 & 62 \\
\hline Serbia & 39 & 14 \\
\hline Slovakia & 45 & 38 \\
\hline Slovenia & 51 & 6 \\
\hline Turkey & 276 & 45 \\
\hline Ukraine & 200 & 72 \\
\hline
\end{tabular}

Tab. 2. Number of existing and planned shopping centers in selected countries in 2012 
Tab. 2 shows that Italy holds the first place by the number of shopping centers in selected European countries and it is followed by Germany, Poland and Turkey. Croatia is close to the rear, while lower values were recorded for Albania, Bosnia \& Herzegovina, Bulgaria, Greece, Kosovo, Macedonia, Montenegro, Serbia, Slovakia and Slovenia. Right part of the table 1 shows number of shopping centers in the pipeline; due to the crisis that is still strong in monitored markets these forecasts may be too positive.

Some of the largest shopping centers in the area of Central and Southeastern Europe are shown in Tab. 3.

\begin{tabular}{|l|c|c|c|}
\hline \multicolumn{1}{|c|}{ Shopping Center } & Opening year & GLA m ${ }^{2}$ & No. of stores \\
\hline $\begin{array}{l}\text { SCS Shopping } \\
\text { Mall, Austria }\end{array}$ & 1976 & 173,000 & 330 \\
\hline Westgate, Croatia & 2009 & 90,000 & 250 \\
\hline $\begin{array}{l}\text { OC Letnany, Czech } \\
\text { Republic }\end{array}$ & 1999 & 110,000 & 190 \\
\hline $\begin{array}{l}\text { Avion Shopping } \\
\text { Park, Czech Rep. }\end{array}$ & 2001 & 108,400 & 142 \\
\hline $\begin{array}{l}\text { Ruhr Park, } \\
\text { Germany }\end{array}$ & 1964 & 126,000 & 96 \\
\hline $\begin{array}{l}\text { Paunsdorf Center, } \\
\text { Germany }\end{array}$ & 1994 & 114,900 & 110 \\
\hline Etnapolis, Italy & 2005 & 110,0000 & 220 \\
\hline $\begin{array}{l}\text { Porta di Roma, } \\
\text { Italy }\end{array}$ & 2007 & 85,000 & 230 \\
\hline $\begin{array}{l}\text { Arkadia, Poland } \\
\text { Baneasa Shopping } \\
\text { City, Romania }\end{array}$ & 2004 & 130,400 & 170 \\
\hline $\begin{array}{l}\text { Avion Shopping } \\
\text { Park, Slovakia }\end{array}$ & 2002 & 119,700 & 500 \\
\hline BTC City, Slovenia & 1993 & 300 \\
\hline $\begin{array}{l}\text { Forum Marmara, } \\
\text { Turkey }\end{array}$ & 2011 & 250 \\
\hline $\begin{array}{l}\text { Marmara Park, } \\
\text { Turkey }\end{array}$ & 2012 & 13000 & 270 \\
\hline
\end{tabular}

Tab. 3. Comparison of the Central and Southeastern European largest Shopping Centers

A shopping center cannot generate more purchasing power than already exists within the trade area, but could cause a redistribution of expenditures. For this reason, a comprehensive market analysis should examine the types of retail facilities and stores available in the trade area, as well as those that will come to the market soon. 
Delic, M. \& Knezevic, B.: Development of Shopping Centers in Central and Southea...

As the shopping center floor-space is growing to a certain point and thus reducing the trend of their construction, emphasis is placed on the redesign of existing and customizing their offerings to different segments of the population.

Tab. 4 shows that the first place in total shopping center floor-space in selected European countries has Germany, followed by Italy, Turkey and Poland. Most surprising is that Slovenia, which is at the very bottom in total shopping center floorspace among selected countries in Central and Southeastern Europe, has the largest number of shopping center square meters per capita, and followed by Austria, Croatia, Ukraine and Italy.

\begin{tabular}{|c|c|c|c|}
\hline Country & $\begin{array}{l}\text { Total shopping } \\
\text { center floor- } \\
\text { space (sq m) }\end{array}$ & $\begin{array}{l}\text { Population in } \\
\text { 2011. (in `000) }\end{array}$ & $\begin{array}{c}\text { Total shopping } \\
\text { Center floor-space } \\
\text { per capita }\end{array}$ \\
\hline Albania & 206702 & 3195 & 64 \\
\hline Austria & 2714540 & 8223 & 330 \\
\hline $\begin{array}{l}\text { Bosnia \& } \\
\text { Herzegovina }\end{array}$ & 381100 & 3792 & 100 \\
\hline Bulgaria & 821400 & 7365 & 111 \\
\hline Croatia & 1158200 & 4291 & 269 \\
\hline Czech Republic & 2193002 & 10520 & 208 \\
\hline Germany & 15497459 & 81716 & 190 \\
\hline Greece & 554600 & 10788 & 51 \\
\hline Hungary & 1122000 & 9989 & 112 \\
\hline Italy & 14070114 & 60394 & 233 \\
\hline Kosovo & 32000 & 1740 & 18 \\
\hline Macedonia & 206600 & 2062 & 100 \\
\hline Moldova & 111900 & 3559 & 31 \\
\hline Montenegro & 52400 & 620 & 84 \\
\hline Poland & 8400000 & 38538 & 218 \\
\hline Romania & 1206192 & 19013 & 63 \\
\hline Serbia & 543100 & 7121 & 76 \\
\hline Slovakia & 1012200 & 5440 & 186 \\
\hline Slovenia & 731600 & 1997 & 366 \\
\hline Turkey & 8193594 & 74724 & 110 \\
\hline Ukraine & 1890530 & 45611 & 236 \\
\hline
\end{tabular}

Tab. 4. Total shopping Center floor-space per capita in selected countries in 2012

The sales potential and resulting cash flow of a retail entity is of critical importance to developers and their financial partners, to retailers, and to institutional investors. For the developer, market area demand analysis is used to determine what and where to build. For the retailer, anticipated sales and consumer research are used to design and locate stores and to define merchandising strategy. For institutional investors and owners, sales levels and forecasts are used to evaluate acquisition pricing to analyze capital improvement paybacks. 
The sales potential for most retail venues is a function of the economic and demographic characteristics of the area in which it is located. There are four key variables that define the economic base: employment, population, income, and retail sales (White \& Gray, 1996).

Investors and retailers rate alternative locations in terms of the size, composition, and growth potential of the employment base. Employment data are used to measure total job growth. The European shopping center industry accounts for approximately a quarter of all retail jobs and another $20-40 \%$ of the European commercial real estate employment. The International Council of Shopping Centers estimates that the European shopping center industry employed 5.3 million retail workers in 2012 and another 1-2 million workers in the real estate development, management and leasing area (ICSC EUROPE, 2012).

Among the selected countries, most shopping center retail positions and highest sales have Germany, Italy, Poland, Turkey and Austria. Serbia, Bulgaria and Bosnia \& Herzegovina are at the bottom of scale (Fig. 2).

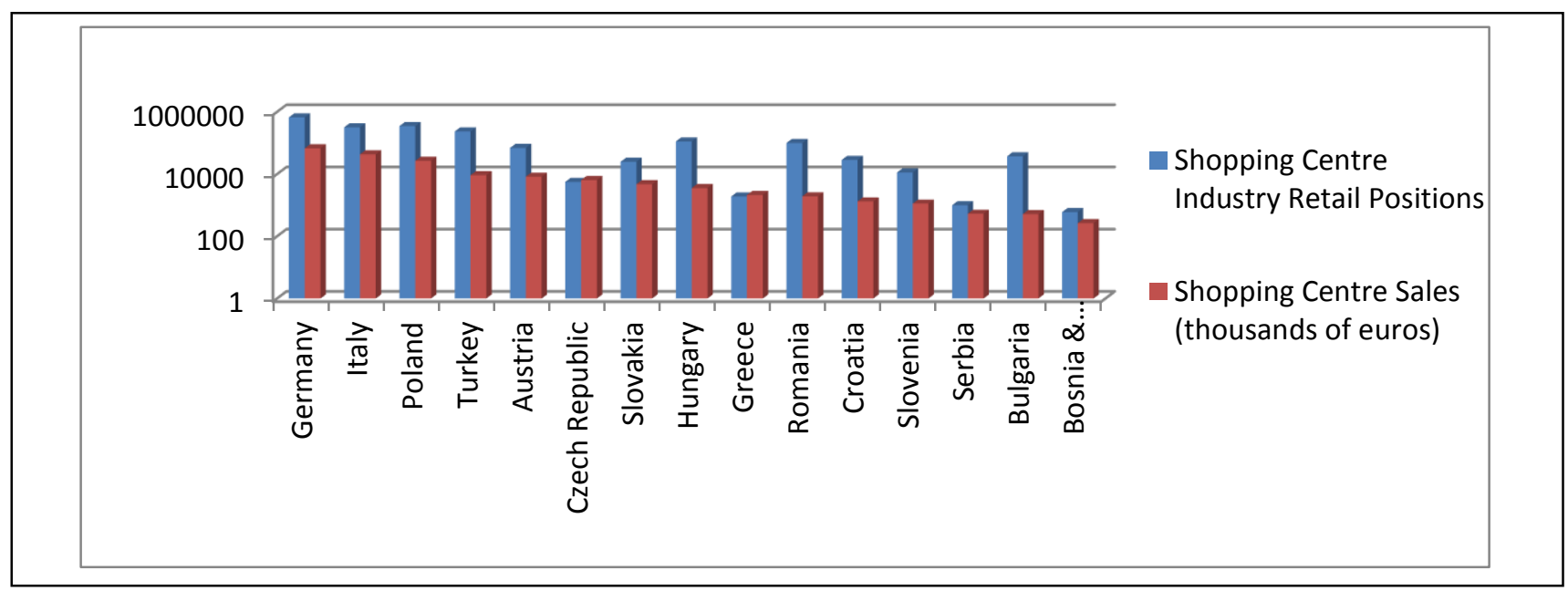

Fig. 2. Shopping Center Employment and Sales in 2012

Income is highly correlated with employment and socioeconomic status, and represents the single best predictor of retail sales. Past and present levels of actual retail expenditures are next important variable in economic base analysis. Retail sales numbers are compared to income averages to determine if higher or lower proportions of income are devoted to different types of goods.

Expenditure on retail goods has a far-reaching impact on the European economy through the supply chain, which encompasses the manufacturing and distribution sectors as well as merchandising. Retail sales are the most-timely indicator of broad consumer spending patterns and make an important contribution to GDP. The final consumption expenditure of households accounted for at least half of GDP in the majority of EU Member States (average 56.9\%) in 2012 (ICSC EUROPE, 2012).

It is interesting to look at the relations between the purchasing power of the population and the number of square meters of shopping centers (Fig. 3). The gross domestic product is used as a measure of the purchasing power of the population. It is 
evident that Kosovo and Montenegro are leading with indicator over 120, which suggests that there is a space for construction of new shopping centers on these markets. The lowest indicator recorded Germany, Italy, Ukraine, Poland and Turkey, that confirms thesis about "inflated" forecasts for number of shopping centers in the pipeline on German, Polish and Turkish market. Most developed economies are respectively located at the bottom scale, suggesting the relative saturation in these markets.

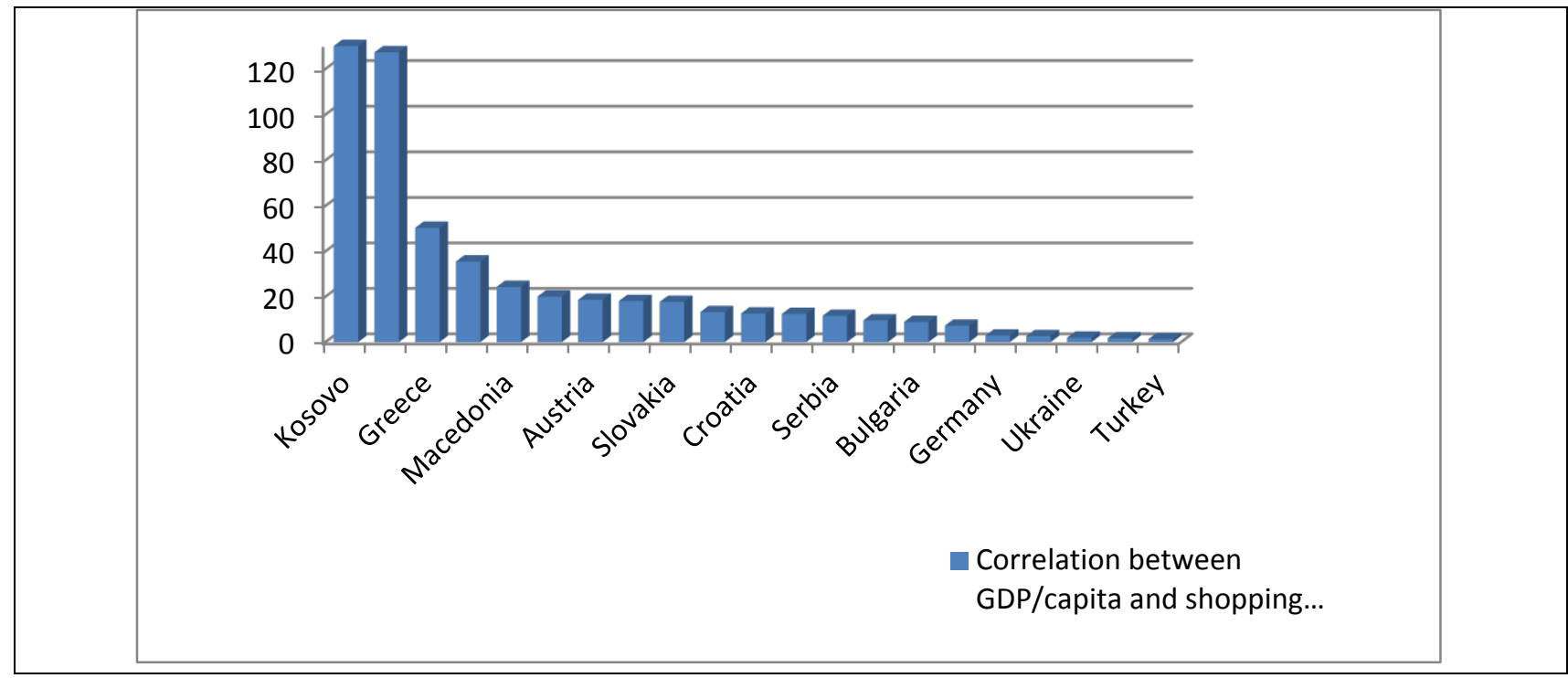

Fig. 3. Correlation between GDP/capita and shopping center GLA (sqm/1000 inhabitants, \$/capita) in selected countries in 2012

Each shopping center pro forma reflects the minimum rent expectations of the owner. It is derived from the owner's investment objectives for the asset and is tempered by conditions of the marketplace and the competition. Rent is determined by market forces such as supply, demand, location, and physical condition, and is also a product of negotiation.

In the prevailing environment of economic uncertainty in the region, some retailers prefer to take advantage of very competitive lease terms and expand into shopping centers rather than opening high street flagship stores, sustaining strong tenant demand for available spaces. Prime shopping centers continue to be strategic destinations for both international and local retailer expansions, often offering access to a higher quality tenant mix, more modern spaces and layouts and benefits such as free parking compared to high street locations.

Rental rates in prime shopping centers remain largely stable, with annual growth rates between zero and $0.5 \%$ on average. Not surprisingly, countries seeing the strongest levels of economic expansion are also experiencing the strongest year-overyear rent growth, including Poland $(+7 \%)$ and Turkey $(+4 \%)$. Germany has also emerged as a safe harbor in Europe in the eyes of many international retailers; helping push prime shopping center rents there up $4 \%$ year-over-year, although the limited new supply in the country is slowing international retailer expansion (A Global Perspective on the Shopping Center Industry, 2012). 


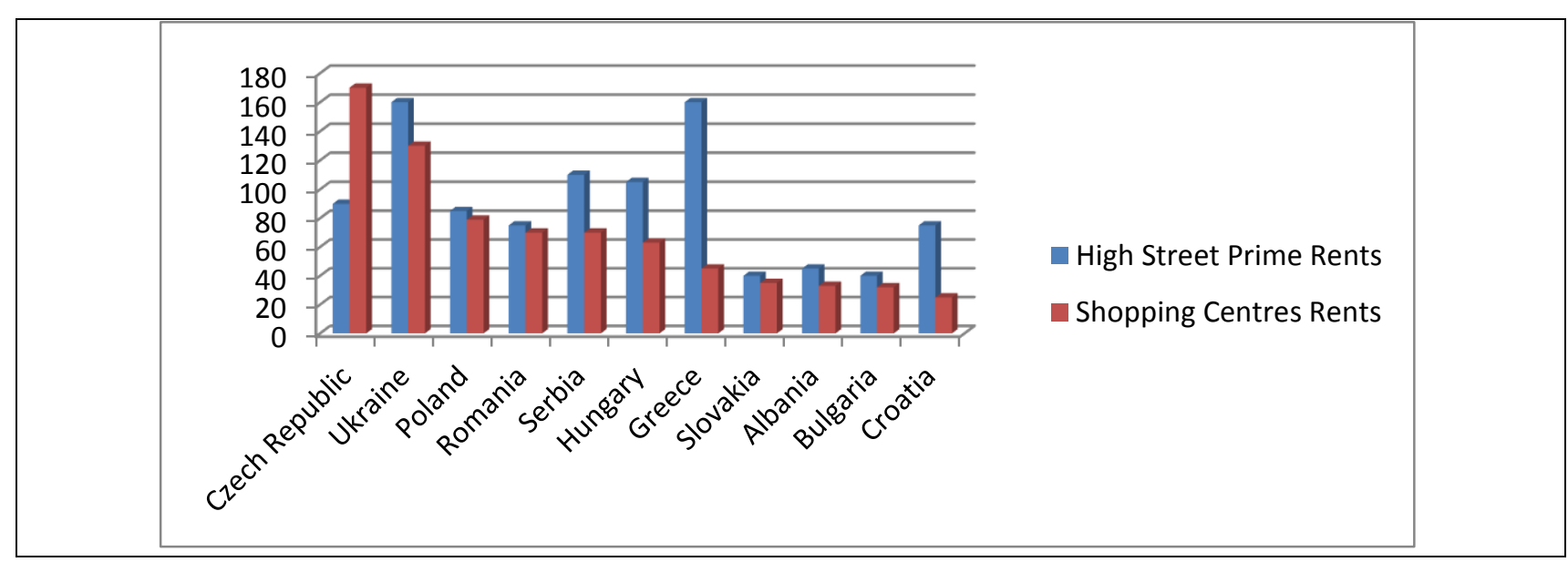

Fig. 4. Main rental levels in selected countries in 2012 (EUR/sqm/month)

Fig. 4 shows main rental levels in selected countries of Central and Southeastern Europe. It is evident that Ukraine has extremely high shopping center and high street prime rents, followed by Greece in high street prime rents and Czech Republic in shopping center rents.

\section{Modern trends in shopping centers development}

The shopping center is a commercial land use that is more than a real estate venture. It is also a retail merchandising complex that provides many of the basic goods and services that a community requires but also functions to a greater or lesser extent as a social and community center.

While economic performance may differ between the mature and emerging markets, there are far reaching changes in consumer preferences, spending patterns and technological advances that are impacting owners and retailers in all markets. Consumer demands and attitudes are driving retailers to change their formats, as are changes in technology and distribution. Consumers seek better values, improved systems, and more convenience.

Since the start of the entertainment wave, shopping center owners have striven to obtain tenant mixes that draw traffic from the widest audience possible. Under one roof or in an outdoor retail format, consumers enjoy children's playscapes, virtual reality games, live shows, movies in multiplex cinemas, and variety of food. Many shopping centers are also focused on added service-oriented tenants, which offer today's busy consumer an opportunity to engage in a variety of other activities (ICSC, 2014).

Consumers are adapting their shopping habits in response to changing economic conditions and retailers are adapting their offer to respond to new consumer demands. Large retailers now offer many of their products online through the Internet. Image interactive technology (IIT) gets more significance offering innovative way to present products and stimulate product experience in a virtual world (Dragičević et al., 2012).

Two major retailers have recently introduced new distribution channels - web shops - hopping to attract young, time scarce and technologically literate consumers. 
Delic, M. \& Knezevic, B.: Development of Shopping Centers in Central and Southea...

As a result of the increasing maturity of e-commerce as a shopping channel, no longer is shopping center performance driven exclusively by the mere presence of popular retailers, food and entertainment options. Shopping center owners are seeking creative ways to attract visitors and better serve the needs of their tenants, ranging from developing smartphone applications, creating virtual malls and producing events via social media sites to drive visitor traffic and create a compelling shopping experience where the mall remains a relevant place to gather (A Global Perspective on the Shopping Center Industry, 2012).

In global marketplaces, purchasing and consumption are not limited to a traditional physical form as they are in shopping centers, but can take place in virtual locations, which have attracted and maintained contacts with a very high number of clients and visitors in the last thirty years. The first virtual purchasing and consumption locations developed in the form of virtual marketplaces, where sellers and customers can meet to buy and sell, both with the mechanism of the traditional fixed price, and with various forms of auction (Reinartz, 2002).

The first forms of online purchases were those created by manufacturing companies which, after having opened an internet site to present their activities, tried to extend their conventional selling channels to the electronic channel, creating online shop windows and developing e-commerce portals to manage new and different ways of relating with their customers.

Whilst on-line retail is barely scratching the surface of the Eastern European market it only represents around 3,5 percent of sales in the more mature market of Poland, relative to around 10 percent in Germany (Harrington \& Priesemeister, 2013).

On-line retail will continue to grow significantly. So, refurbishment and maintenance of existing commercial projects with stability and quality are a prerequisite for future positive trends.

\section{Conclusion}

Analysis of consumers' perceptions conclude that modern consumers do not perceive shopping centers only as a retail space, but also as a place to spend their leisure time and realize other social needs. Since the experience and sociological moment of purchase is extremely important to customer, classic shopping centers will always be an attractive area of sales, promotions and entertainment. However, considering the development of modern technology, dynamic way of life and reduced investment opportunities in retail businesses, development of online shopping centers that would retain the business concept of the classic shopping center is increasingly evident. Therefore, it can be concluded that online shopping centers are the next step in the development of retail, but on the other hand the classic shopping centers will not lose its importance in the retail concept. The challenge is for retailers and shopping center developers to take advantage of opportunities that exist in diverse retail environments.

The economic base analysis provides the investor or developer with an empirical assessment of the total area size, key elements of the composition of demand, and growth trends. It is important to consider these development trends in the wider context of the retail landscape as a whole. In some countries with less history of city center, downtown or high street retail formats, shopping centers remain the only 
option. In others there is a well-established tradition of strong retail provision in town and city centers and so shopping centers add yet another dimension to the overall retail offering for consumers. As the impact of the global financial crisis continues to ripple through markets, the shape of the global retail development sector will continue to evolve and adapt over the next few years. Developers, retailers and investors will continue to face challenges as the sector evolves, with new market drivers, such as the growth of e-tailing and multi-channel retailing.

The future of shopping center development will be highly competitive, and this will be the case not just between retailers, but also between locations. The analysis of selected markets in Central and Southeastern Europe in the paper shown that markets such as Kosovo, Montenegro, Greece and Macedonia still have potential for improvement in the market of shopping centers.

In addition, by adding the virtual dimension, there will be increasing competition between bricks and clicks and how not only shopping centers position themselves, but also how supply chains may need to transform to accommodate this. Despite rapid changes in technology and how consumers shop and interact with brands, the physical shopping center is still at the heart of retail experience. Successful retailers and owners will be those who are able to partner and carefully evaluate opportunities for revenue, profitability and expansion.

Due to internationalization, rapid changes in business and the presence of economic crisis, trend in the future is not predictable with certainty, but there are indications what it might be. The crisis will not completely stop the retail investment activity because they are related to everyday consumer spending. The intensity and dynamics are likely to change and, as a consequence, investors will not make decisions about entries into new markets and investing in new projects easily any more. Conclusion is that the investment activity will continue to exist, but in the smaller volume and intensity.

\section{References}

Beyard, M. \& O'Mara, W. P. (2006). Shopping Center Development Handbook, Third Edition, Urban Land Institute, ISBN: 0-87420-852-1, Washington, D.C

Corniani, M. (2011). Shopping Centers and Intangible Consumption in Global Cities, Symphonya, Emerging Issues in Management, No. 1, (2011), page numbers (41-54), ISSN: 1593-0319

Dragičević, M., Letunić, S., Majić, M. (2012). The consumers' attitudes towards retailers' strategies applied on the Dubrovnik area, Annals of DAAAM for 2012 \& Proceedings of the 23rd International DAAAM Symposium, Katalinic, B. (Ed.), Vol. 23, No.1, pp. 107-110, ISBN: 978-3-901509-91-9, Published by DAAAM International, Vienna

Harrington, D. \& Priesemeister, J. (2013). Research \& Forecast Report 2013: Eastern Europe - Retail Market Overview, Available from: http://www.colliers.com//media/Files/EMEA/EasternEuropeaninformation/Retail-Market-Yearend\%20Snapshot-2013.pdf.pdf

Markerink H. J. \& Santini A. (2004). The Development of Stadiums as Centers of Large Entertainment Areas. The Amsterdam Arena Case. Symphonya. Emerging Issues in Management, No. 2, (2004), page numbers (47-72), ISSN: 1593-0319 
Property EU: Expo Real Special: Rise of the Green Mega deal, October 2009 Reikli, M. (2013). Value creation or value destruction in the shopping centre industry? The Rise and Fall of Shopping Centers in Romania, International Journal of Management Cases, Vol. 15, No. 4, page numbers (274-286), ISSN: 1741-6264

Reinartz W. J. (2002). Customizing Prices in Online Markets. Symphonya. Emerging Issues in Management, No. 1, (2002), page numbers (55-65), ISSN: 1593-0319

Segetlija, Z. (2006). Trgovinsko poslovanje (Trade Operations), Ekonomski fakultet u Osijeku, ISBN: 953-253-005-3, Osijek

Šulmajster Šodić, M. (2008). Rastuće tržište shopping centara - poduzetnički pristup i održivi razvoj (Growing market of shopping centers - Enterprise Access and Sustainable Development), Available from: http://books.google.hr/books

White, J. R. \& Gray K. D. (1996). Shopping Centers and Other Retail Properties, John Wiley \& Sons, Inc., ISBN: 0-471-04002-9, Canada

***(2014a) http://www.globalpropertyguide.com/Europe/gdp-per-capita_ - Europe: GDP per capita (2012), Accesed on: 2014-09-15

***(2014b) http://www.tradingeconomics.com/kosovo/gdp-per-capita- Kosovo: GDP per capita (2014), Accesed on: 2014-09-15

***(2014c) http://www.retailcenters.eu/ - RegioData Shopping Center Explorer for selected countries, RegioData Research GmbH Vienna (2012), Accesed on: 2014-0825

***(2014d) European Retail Guide. Shopping Centers (2013). Available from: http://www.dtz.dk/files/other/Markedsrapport/dtz_european_retail_guide__shopping_centres_march_2013.pdf

***(2014e) 2012 Eastern Europe Real Estate Review (2012). Colliers International, Available from: http://www.colliers.com/ /media/files/emea/emea/research/marketoverview/2012-eastern-europe-real-estate-review.ashx

Consultant business Richard Ellis: www.cbre.com

***(2014f) The Importance of the European Shopping-Center Industry. A Snapshot of its Retail Sales Impact in 2012 (2012). Available from: http://www.google.hr/url?sa=t\&rct=j\&q=\&esrc=s\&source=web\&cd=1\&ved=0CBoQF jAA\&url=http\%3A\%2F\%2Fwww.prch.org.pl

***)2014g) 2014 Economic Impact of Shopping Centers (2014). Available from: http://www.icsc.org/uploads/default/2014-Economic-Impact-Kit.pdf

$* * *(2014 \mathrm{~h})$ The importance of shopping centers to the economy in the Nordic countries (2009). Nordic Council of Shoppping Centers. Avalilable from: http://ncsc.se/files/publications/NCSC_White_PaperX_ENny.pdf

***(2014i) A Global Perspective on the Shopping Center Industry (2012). A Cushman \& Wakefield Research Publication. Available from: http://www.cushmanwakefield.com Marketbeat Shopping Center Development Report Europe (2013). A Cushman \& Wakefield Research Publication. Available from: http://www.cushmanwakefield.com

***(2014j) Global Shopping Center Development Report: Americas, Europe, Asia (2014). A Cushman \& Wakefield Research Publication. Available from: http://www.cushmanwakefield.com

***(2014k) Neglected real estate markets Bulgaria and Romania? (2014). Real Estate Country Facts. Available from: http://www.bankaustria.at 